\title{
Analysis and forecast of textile industry technology innovation capability in China
}

DOI: 10.35530/IT.072.02.1759

\section{ABSTRACT - REZUMAT}

\section{Analysis and forecast of textile industry technology innovation capability in China}

The textile industry of China has been facing with fierce competition and transformational pressures. It is of great significance to study the evolution of textile industry's technological progress and to predict the trends. The study analyses the technological innovation ability of China's textile industry based on the data of 270,145 patent applications from 1987 to 2016. At the same time, the Logistic model is used to forecast the technology innovation capability of China's textile industry. The study found out: the number of Chinese textile patent applications is on a upward trend; enterprises and universities are the most important patentee; the regional distribution of textile technology innovation is uneven; the number of patent applications in the southeast coastal areas is the largest; the distribution of the IPC is also uneven, D06 (fabric treatment) having the largest number of patent applications and the fastest growth rate; China's textile industry technology innovation has entered a maturity stage in 2018, and will enter the recession stage after 2027 based on the Logistic model.

Keywords: textile industry, patent analysis, technology life cycle, S-shaped Growth Curvetrend forecast

\section{Analiza și prognoza capacității de inovare tehnologică a industriei textile din China}

Industria textilă din China s-a confruntat cu o concurență acerbă și cu presiuni de transformare. Studierea evoluției progresului tehnologic al industriei textile și prognoza tendințelor au o mare semnificație. Studiul analizează capacitatea de inovare tehnologică a industriei textile din China pe baza datelor a 270.145 de cereri de brevet din perioada 1987-2016. În același timp, modelul logistic este utilizat pentru a prognoza capacitatea de inovare tehnologică a industriei textile din China. Studiul a concluzionat următoarele: numărul cererilor de brevet din industria textilă din China înregistrează o tendință ascendentă; întreprinderile și universitățile dețin cele mai multe brevete; distribuția regională a inovației tehnologice textile este inegală; numărul cererilor de brevet în zonele de coastă sud-estice este cel mai mare; distribuția IPC este, de asemenea, inegală, D06 (tratarea țesăturii) având cel mai mare număr de cereri de brevet și cea mai rapidă rată de creștere; inovația tehnologică în industria textilă din Chinei a intrat într-o etapă de maturitate în 2018 și va intra în etapa de recesiune după 2027 pe baza modelului logistic.

Cuvinte-cheie: industria textilă, analiza brevetelor, ciclul de viață al tehnologiei, prognoza Curvetrend de creștere în formă de $S$

\section{INTRODUCTION}

The textile industry of China has made great achievements since the late 1970s. From 2006 to 2016, the annual growth rate of industrial added value of industrial enterprises above designated size was $9.48 \%$, and the average annual compound growth rate of total profit was $15.15 \%$. According to the " $13^{\text {th }}$ FiveYear Plan for Textile Industry" issued by the Ministry of Industry and Information Technology in September 2016, the proportion of China's total textile exports to the world has increased from $10.42 \%$ in 2000 to $38.60 \%$ in 2015 . At present, as China's economy shifts from a high-speed growth stage to a high-quality development stage, the textile industry has entered a new stage of comprehensively promoting high-quality development, and technological innovation is undoubtedly an important guarantee for highquality development.
Technological innovations are critical to the development of technology strategies and policies, tracking the historical process of technological innovation and predicting future trends [1]. Patents are an effective indicator to measure technological innovation. The amount of patent applications can directly reflect the R\&D strength and output level of the innovative subject [2]. Patent analysis is the most accurate method to predict short- and medium-term technological developments [3]. Analysis of patent-related historical information such as regional distribution and field distribution can accurately predict the main competitors, as well as the development of core technologies at various stages [4]. More and more industrial technology researches are based on patents $[5,6]$. Nicolas Grandjean believes that patent information analysis can provide information on industrial technology activities, research and development trends, emerging fields, and cooperation [7]. Alan Porter and 
Nils Newman mined patent texts to study industrial technology innovation models [8]. Luan analysed global electric vehicle patents and found that electric vehicle patent high-yield institutions and hot technology fields [9].

The development of industrial technology is similar to the evolution process of life from birth, growth, maturity, decline, and death. It will experience different characteristics in different stage [10]. An analysis of the stage of the technology life cycle (TLC) can accelerate the forward-looking layout of industrial technology R\&D and can also promote the sustainable development of the textile industry. A commonly used method to evaluate the TLC is the S-shaped growth curve [11]. Huang [1] used the S-curve method to analyse the development trajectory of 3D printing technology. It believed that 3D printing technology began to sprout in 1985-2004, and began to enter the growth stage in 2005, and predicted to enter maturity in 2016. Boretos [12] uses the S-curve to predict mobile phone trends. Chen et al. [13] compared the life cycle and development potential of the two technical fields of hydrogen energy and fuel cell, and predicted its development prospects. Daim et al. [14] also used S-curve to predict the development of three emerging technologies in fuel cell, food safety and optical storage. Liu and Wang [15] used S-curve and Logistic models to predict the trend of Japanese biped robot walking technology, and believed that the technology will continue to develop in Japan for decades.

In summary, the current researches on technical capabilities and technology trends are mostly focused on the micro-level technical field, while there are fewer studies on patent analysis and prediction on the industrial level. Besides, the technology innovation research based on patent analysis of textile industry is relatively lacking. With the new round of textile technology revolution, more precise research is needed on textile technology capabilities and technological innovation trends. The study analyses the patents to measures the trend, the regional distribution of applications and the technical fields. At the same time we use the method of S-Shaped Growth Curve to predict the trend of China's textile industry.

\section{DATA SOURCE}

The data comes from the textile industry patent information service platform (http://chinaip.sipo.gov.cn). According to the International Patent Classification, the technical fields related to patents are divided into eight parts: A, B, C, D, E, F, G, and H. Textile technology, together with papermaking technology, is in the Part D, including D01-D07, D21 (paper and other small categories). D01-D06 represents the aspects of raw materials, spinning, weaving, knitting, sewing and fabric treatment; D07 is the rope technology. Compared with the patent application, the information of patents grants may be delayed due to the time. In different years, there is a deficiency for patent grants to reflect the trend of technological innovation
[13]. Therefore, the research selects the data of patent application. D01-D06 was selected to retrieve the invention patents and utility model patents applied between 1987 and 2016. The search term used is: IPC=D01 or D02 or D03 or D04 or D05 or D06 (table 1).

\begin{tabular}{|c|l|}
\hline \multicolumn{2}{|l|}{ IPC DISTRIBUTION OF TEXTILE PATENT } \\
\hline IPC Class & \multicolumn{1}{|c|}{ Name 1} \\
\hline D01 & Natural or chemical thread or fibre; spinning \\
\hline D02 & $\begin{array}{l}\text { Mechanical finishing, warping or mecha- } \\
\text { nization of yarns, yarns or ropes }\end{array}$ \\
\hline D03 & Weaving \\
\hline D04 & $\begin{array}{l}\text { Weaving, lace making, knitting, sash, non- } \\
\text { woven fabric }\end{array}$ \\
\hline D05 & Sewing, embroidering, tufting \\
\hline D06 & $\begin{array}{l}\text { Fabric processing, washing, flexible materi- } \\
\text { als not included in other types }\end{array}$ \\
\hline
\end{tabular}

\section{METHODS}

\section{Patent analysis}

The number of patents, types of patents, and categories of patents reflects the trend of technological innovation in the industry. Through the analysis of these information, we can understand the technological innovation capabilities of industries and formulate corresponding countermeasures [16]. The patent measurement method can be used to grasp the spatial and temporal distribution of countries and regions, enterprises and inventors distributed in a certain technical field to analyse the transfer of technology centres and the rise and fall of enterprises and industries. Enterprises can grasp the competitive situation, formulate corresponding countermeasures, and predict development trends by measuring their own patents and competitors' patents. The study reveals the layout and competition of textile industry technology innovation from the perspective of patent application trend, applicant distribution, and technical field distribution to reflect China's textile technology innovation capability and development trend.

\section{Technology life cycle theory and logistic model}

The technology life cycle theory believes that the development of technology can be divided into four stages: (1) at the germination stage, there are few technological innovations, mostly basic innovations, and the technical direction is uncertain; (2) during the growth phase, new technologies continue to extend into the entire field. Technology becomes more attractive and more innovative entities are involved in R\&D. Innovation subjects and outputs are proliferating; (3) at the maturity stage, the R\&D technology is mature. But due to the market restriction, the number of patent applicants is basically unchanged. The growth rate of technological innovation is also slowing down; (4) during the recession period, the technology is aging. The company gets lower profits and 
withdraws from the market, resulting in a decrease in the number of technological innovations. The entire industry needs new and alternative technologies to emerge, which will trigger a new round of technological changes. Kim [17] proposes the use of patent data for technical life cycle judgment. With time as the horizontal axis and patent application for the vertical axis to create visual graphics, the shape of the technology trend seems like the English letter "S". The curve changes correspond to different stages of the technology life cycle, as shown in figure 1. This method has been widely recognized.

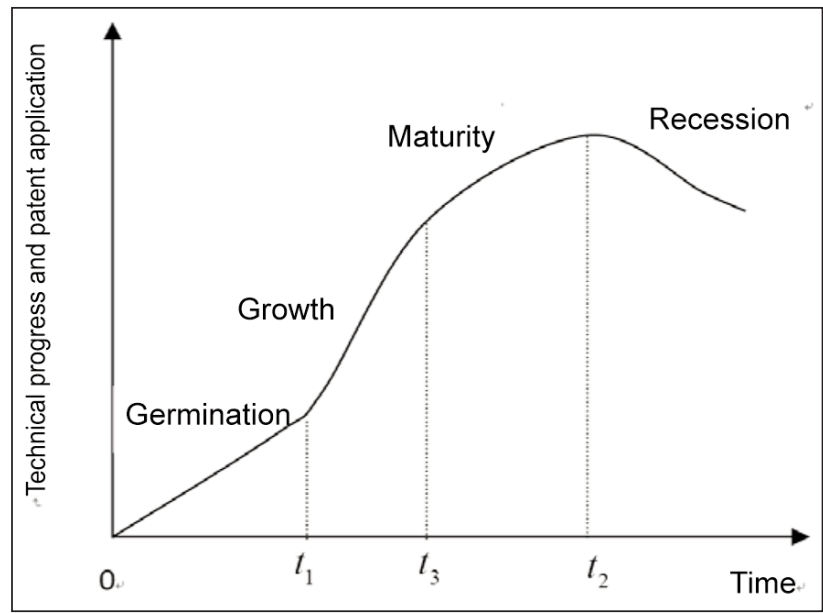

Fig. 1. S-shaped Growth Curve of the technology life cycle

The study uses the Logistic model to measure the technology life cycle. Assume that the abscissa is time $t$, the ordinate is the cumulative amount of patent $f(t)$. The Logistic curve formula is $y=\frac{k}{1+a e^{-k b t}}$ ( $k$ for the maximum amount of accumulation, $a, b$ are constants, $t$ for time). The first derivative is:

$$
\frac{\mathrm{d} y}{\mathrm{~d} t}=\frac{-k *(-k b) * a \mathrm{e}^{-k b t}}{\left(1+a \mathrm{e}^{-k b t}\right)^{2}}=\frac{b k^{2}\left(\frac{k}{y}-1\right)}{\frac{k^{2}}{y^{2}}}=b y(k-y)
$$

If $\frac{\mathrm{d} y}{\mathrm{~d} t}=0$, then $y=0$ or $y=k$. This equation shows that there is no maximum or minimum between these two limits and is therefore monotonic.

The second derivative is:

$$
\begin{gathered}
\frac{\mathrm{d}^{2} y}{\mathrm{~d} t^{2}}=b k * \frac{\mathrm{d} y}{\mathrm{~d} t}-2 b y \frac{\mathrm{d} y}{\mathrm{~d} t}=b * \frac{\mathrm{d} y}{\mathrm{~d} t}(k-2 y)= \\
=b^{2} y(k-y)(k-2 y)
\end{gathered}
$$

If $\frac{\mathrm{d}^{2} y}{\mathrm{~d} t^{2}}=0$, then $y=0, y=k, y=\frac{k}{2}$, there is a unique inflection point $y=\frac{k}{2}$, substitute $y=\frac{k}{1+a e^{-k b t}}$, get $y=\frac{\ln a}{b k}$, that is, the inflection point coordinates are $\left(\frac{\ln a}{b k}, \frac{k}{2}\right)$. Below the inflection point, the curve is convex downward; above the inflection point, the curve is convex. The cumulative amount changes from rapid growth to slow growth, so this point can be regarded as the cut-off point between growth and maturity, which is recorded as $t_{0}=\frac{\ln a}{b k}$.

In general, when the cumulative amount reaches $10 \%$, the curve enters the growth phase from the introduction period, and the time boundary point is recorded as $t_{1}$. When the cumulative amount reaches 90, the curve enters the recession period from the maturity period, and the time boundary point is recorded as $t_{2}$. The time of growing is the time interval between the growth period and the maturity period, recorded as $t_{3}$, as is in figure 1 .

Since the Logistic curve is a symmetric S-curve, the boundary point coordinates of each period can be derived using its image properties.

The logic curve is symmetric about the centre of the inflection point $\left(\frac{\ln a}{k b}, \frac{k}{2}\right)$. Therefore, the curve of the cumulative amount from $10 \%$ to $90 \%$ is also symmetric about the centre of the point $\left(\frac{\ln a}{k b}, \frac{k}{2}\right)$. Then the growth period is the same as the maturity time, that is $\frac{t_{3}}{2}$. And the time boundary between the introduction period and the growth period is $t_{1}=t_{0}-\frac{t_{3}}{2}$ The time demarcation point between maturity and recession is $t_{2}=t_{0}+\frac{t_{3}}{2}$. The dividing point between growth and maturity is $t_{0}=\frac{\ln a}{b k}$.

The study uses Loglet-Lab2 software for life cycle estimation. The results of the Loglet Lab software include three parameters: Saturation, Growth Time, and Midpoint [18]. Saturation is the maximum utility value generated by using a certain technology; Growth Time is $10 \%-90 \%$ of the maximum utility value generated by a certain technology; Midpoint is the inflection point of the $S$ curve, the technical utility growth rate reaches a maximum at this point.

\section{ANALYSIS AND DISCUSSION}

\section{Trends of textile technology innovation}

The number of patent applications reflects the innovation ability in the industrial or technical field to a certain extent. From 1987 to 2016, the number of textile industry patents in China is 270,145 totally, including 148,489 invention patents and 121,656 utility models. The number of patent applications and the trend are shown in figure 2. It can be seen from figure 2 that the invention patents and utility model patents of textile industry in China are generally on the rise. From the perspective of patent application trend, the number of applications for invention patents and utility model patents before 2000 was small and the growth was slow, in its infancy stage. Accelerated from 2001 to 2008, invention patents and utility model patents had grown faster than the previous stage. After 2008, with the promulgation and implementation of the National Medium- and LongTerm Science and Technology Development Plan (2000-2020) and the promotion of national science and technology policies, textile patents entered a 


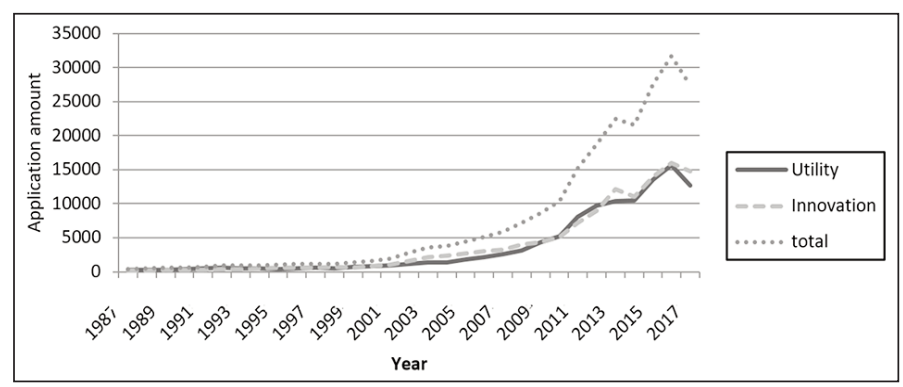

Fig. 2. Annual trends of Chinese textile patent applications from 1987 to 2016

stage of rapid growth. As seen from figure 2, the development curve of invention patents and utility model patents crossed in 2009. In 2010 and 2011, the invention patents were close to utility model patents, and their amount was basically the same.

\section{Regional distribution of textile technology innovation}

The regional distribution of textile patents covers 31 provinces and cities nationwide, and statistics on the total number of patent applications (including invention patents and utility model patents) in the textile sector of each province. Currently, the top ten provinces with most patent applications are Jiangsu, Zhejiang, and Guangdong, Shandong, Shanghai, Anhui, Fujian, Tianjin, Beijing, Hubei (table 2).

Table 2

TOP 10 PROVINCES OF THE TEXTILE INDUSTRY

\begin{tabular}{|c|c|}
\hline Applicant provinces and cities & Number of patents \\
\hline Jiangsu & 80110 \\
\hline Zhejiang & 58831 \\
\hline Guangdong & 20271 \\
\hline Shandong & 19602 \\
\hline Shanghai & 15878 \\
\hline Anhui & 11724 \\
\hline Fujian & 10446 \\
\hline Tianjin & 6768 \\
\hline Beijing & 6730 \\
\hline Hubei & 5257 \\
\hline
\end{tabular}

An analysis of the number of patents in the region finds that the regional distribution of patent applications of textile industry in China was uneven. The patent applications in the eastern coastal areas (including Shanghai, Jiangsu, and Zhejiang) accounted for almost two-thirds of the total applications in the field. It can be seen that the eastern coastal areas have obvious advantages in technological innovation in the textile field, because Jiangsu, Zhejiang and Shanghai are the centre of China's textile industry. In the core area, a large number of textile enterprises have gathered, and they have accumulated a solid technical foundation. At the same time, they have gathered textile universities such as Donghua University, Jiangnan University and Suzhou University. The development of the northern coast (including Beijing, Tianjin, Hebei, and Shandong) is relatively stable. The southern coastal areas (including Fujian, Guangdong, and Hainan) and the middle reaches of the Yangtze River (including Hubei, Hunan, Jiangxi, and Anhui) have developed rapidly in recent years and have become an important role in the technological innovation of the domestic textile industry. The middle reaches of the Yangtze River have a good development momentum and great potential. In the north-eastern region, southwestern regions (Yunnan, Guizhou, Sichuan, Chongqing, Guangxi) and the north-western regions (Gansu, Qinghai, Ningxia), the number of textile patent applications is small, indicating that their textile industry technological innovation is still in a relatively weak state. While undertaking the transfer of the eastern textile industry, the weak region must pay attention to the improvement of independent innovation capability.

\section{Distribution of textile technology innovation fields}

A statistical analysis of the top 20 for patent applications in the textile field finds that companies and universities were important forces (table 3 ). Donghua University has 2,423 textile licensing patents, ranking first, followed by Jiangnan University, Zhejiang University of Technology, Tianjin Polytechnic University, Suzhou University and Wuhan Textile University. There are 14 companies in the top 20 patent applications, including 6 foreign companies, from Korea, Japan, and Switzerland.

\section{Distribution of technological innovation in the textile industry}

The ranking of each textile industry branch technical field according to invention patent applications statistics is the same as that according to total patent applications statistics, and the order from high to low is D06, D01, D03, D04, D05, and D02, as shown in table 4. Except D05, the proportion of invention patents is $49 \%$ and above. The number of invention patents applied in the field of D06 (treatment of fabrics, etc.; washing; flexible materials not included in other categories) and D01 (natural or artificial wire or fibre; spinning) are located in the first and second place respectively, the focus research field of textile technology in China. Then followed by D04 (tape; lace; knitting; finishing). Although the total number of D05 (sewing; embroidery; tufting) is similar to D03, most of D05 are utility model patents, invention patents accounting for a relatively small proportion. The number of patent applications and invention patent applications in the field of D02 (yarn; mechanical finishing of yarn or rope; warping or warping) is the least. 


\begin{tabular}{|c|c|c|c|c|c|}
\hline \multicolumn{7}{|c|}{ TOP 20 INSTITUTIONS OF CHINESE TEXTILE INDUSTRY PATENT APPLICANTS } \\
\hline $\begin{array}{c}\text { Serial } \\
\text { number }\end{array}$ & Applicant & $\begin{array}{c}\text { No. of } \\
\text { patents }\end{array}$ & $\begin{array}{c}\text { Serial } \\
\text { number }\end{array}$ & Applicant & $\begin{array}{c}\text { No. of } \\
\text { patents }\end{array}$ \\
\hline 1 & Donghua University & 3128 & 11 & Matsushita Electric Industrial Co., Ltd. & 797 \\
\hline 2 & Wuxi Little Swan Co., Ltd. & 3113 & 12 & Samsung Electronics Co., Ltd. & 733 \\
\hline 3 & $\begin{array}{c}\text { Qingdao Haier Washing Machine Co., } \\
\text { Ltd. }\end{array}$ & 1779 & 13 & Ritter Machinery & 702 \\
\hline 4 & Jiangnan University & 1610 & 14 & Toray Fiber Research Institute (China) & 683 \\
\hline 5 & Haier Group & 1593 & 15 & Ningbo Cixing Co., Ltd. & 680 \\
\hline 6 & LG Electronics Co., Ltd. & 1355 & 16 & Tianjin Polytechnic University & 673 \\
\hline 7 & $\begin{array}{c}\text { Lejin Electronics (Tianjin) Electric Co., } \\
\text { Ltd. }\end{array}$ & 1201 & 17 & Suzhou University & 661 \\
\hline 8 & Zhejiang Sci-Tech University & 1041 & 18 & Natur DuPont & 650 \\
\hline 9 & Guangdong Esque Textile Co., Ltd. & 967 & 19 & Wuhan Textile University & 639 \\
\hline 10 & Nanjing Lejin Panda Electric Co., Ltd. & 951 & 20 & Qingdao Haier Drum Washing & 559 \\
\hline
\end{tabular}

\begin{tabular}{|c|c|c|c|c|c|c|}
\hline \multicolumn{7}{|c|}{ FIELD DISTRIBUTION OF TEXTILE PATENT APPLICATIONS } \\
\hline Field & D01 & D02 & D03 & D04 & D05 & D06 \\
\hline Utility model & 22829 & 4524 & 11834 & 13306 & 15447 & 43713 \\
\hline Invention patent & 26156 & 6076 & 11442 & 12912 & 8447 & 54550 \\
\hline Total & 48985 & 10600 & 23276 & 26218 & 23894 & 98263 \\
\hline Proportion of invention & 0.53 & 0.57 & 0.49 & 0.49 & 0.35 & 0.55 \\
\hline
\end{tabular}

\section{Technology life cycle prediction}

The study analyses the patent data of textile industry in China from 1987 to 2016, and uses the Logistic model to calculate the technical life cycle of the textile industry. Based on the $S$ curve, the technical trend is predicted to determine the stage characteristics of s textile industry in China. Based on the theory of Logistic Growth, the cumulative product of the patent is the vertical axis, and the patent application year is the horizontal axis. The trend of the textile technology is shown in figure 3 using Loglet Lab software. The dots in the figure indicate the actual number of accumulated patents, and the solid line indicates the estimated accumulative number of patents. The saturation point, growth time and turning point were calculated. As shown in table 5, the cumulative number of patents for the saturation point was $628,841.54$, and the growth time was 19.24 years. The inflection point of the s curve occurred in 2017. The application began in 1987 . The system has estimated its growth time to be 19 years, that is, the patent application continues to grow until 2006, which is the budding period. Then the patent application entered the growth period. This period has shown an accelerated growth trend. It is expected that the textile industry patents will show a decelerating trend from 2018 to 2028, but the total amount is still increasing, and this stage is a mature period. It is expected that the patent saturation value will be $628,841.54$ pieces.
After that, the patent growth will enter a recession period, the space for technology development is small, and the application volume is gradually reduced.

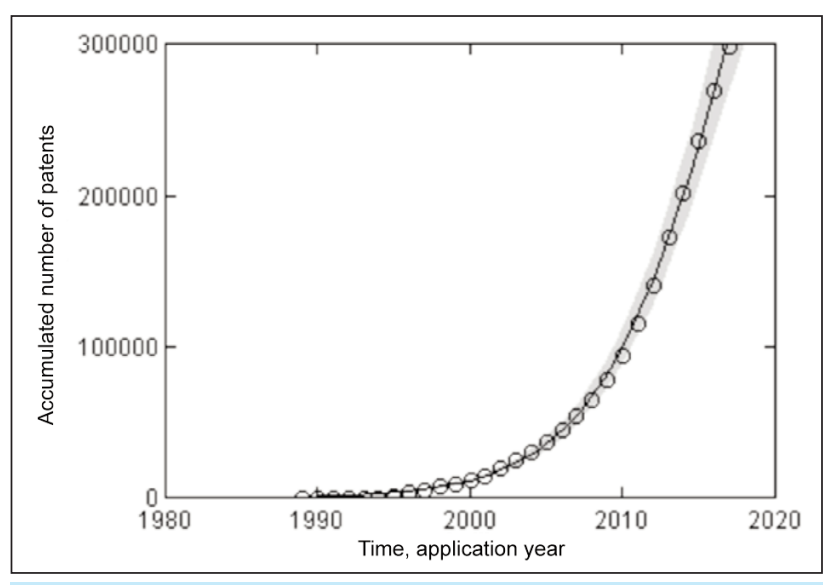

Fig. 3. S-shaped Growth Curve of China's textile industry technology innovation

Table 5

THE RESULT OF S-SHAPED CURVE FITTING

\begin{tabular}{|c|c|}
\hline Variable & Value \\
\hline Saturation & $628,841.54$ \\
\hline Midpoint & $2,017.322$ \\
\hline Growth time & 19.24 \\
\hline
\end{tabular}


The figure 3 indicates that the technical life cycle of the textile industry has entered a mature stage. As shown in table 6, textile industry technology has entered a mature stage in 2018, and the total number of patents is still growing, but the speed is reduced slowly. Innovation of textile industry in China is shifting from pursuing quantity to pursuing quality. The result is consistent with the overall situation of the textile industry. At the mature stage, the industry has strong R\&D capabilities and mature technology. It is the best time for the synergetic development between innovation quantity and innovation quality, most likely to produce key technologies.

Table 6

\begin{tabular}{|c|c|c|c|}
\hline \multicolumn{4}{|c|}{ FORECAST OF TECHNOLOGY GROWTH STAGE } \\
OF TEXTILE INDUSTRY \\
\hline $\begin{array}{c}\text { Budding } \\
\text { stage }\end{array}$ & $\begin{array}{c}\text { Growing } \\
\text { phase }\end{array}$ & $\begin{array}{c}\text { Maturity } \\
\text { stage }\end{array}$ & $\begin{array}{c}\text { Recession } \\
\text { phase }\end{array}$ \\
\hline $1987-2006$ & $2007-2017$ & $2018-2027$ & After 2027 \\
\hline
\end{tabular}

\section{CONCLUSIONS}

Based on the data of textile industry patent application in China from 1987 to 2016, the study uses the patent measurement method to analyse the technological innovation capability, including the distribution of innovation regions and subjects, as well as the distribution and structure of major technical fields. And based on the number of patent applications per year, the Logistic model is used to measure the life cycle stage of textile industry in China.

First of all, the number of technological innovations in the Chinese textile industry has shown a rapid upward trend. However, the growth rate of utility model patent is fast, and its proportion is close to invention patent's proportion. Secondly, the regional distribution of invention patent applications, patentees, and technical fields of the Chinese textile industry from 1987 to 2016 were analysed. It was found that the areas of technological innovation in the Chinese textile industry were mainly distributed on the southeast coast. Enterprises and universities were the important R\&D subjects. The study also found the development was uneven among the six major technical fields of the textile industry, in which D06 (fabric treatment) had the largest number of patent applications and the fastest development rate, while D02 (spinning) had the slowest development rate. Thirdly, using the Logistic model to measure the technology life cycle stage, China's textile industry technology entered a growth stage in 2007 and entered a mature stage in 2018.

Based on the above analysis, first of all, the quality of innovation in China's textile industry needs to be further improved. This requires the competent authorities of the textile industry to play the role of government's macro-control and coordination, to guide and support the technological investment and research of textile enterprises, especially small and mediumsized textile enterprises. The government should provide diverse financing channels, building a good independent innovation platform combining technology and finance, promoting high-quality development of the textile industry. Secondly, the Chinese government should strengthen research and development investment in the textile industry in less developed regions, and guide the textile industry in less developed regions to shift from labour-intensive to innovation-driven. In addition, textile enterprises should choose the direction and field of technological innovation according to their own conditions. Enterprises with strong R\&D capabilities should strive in cuttingedge fields and develop basic patent technologies; those with weaker strengths should avoid fields where patent applications are relatively concentrated and break through weak areas. Finally, the technological research in each sub-sector of the textile industry has entered a mature stage. It is necessary to strengthen the Industry-University-Research cooperation and multidisciplinary integration, starting from new energy, new materials, new technologies and other aspects to promote a new round of technological change.

\section{REFERENCES}

[1] Huang, Y., Zhu, D., Qian, Y., A hybrid method to trace technology evolution pathways: a case study of 3D printing, In: Scientometrics, 2017, 111, 1, 185-204

[2] Griliches, Z., Patent Statistics as Economic Indicators: a survey, In: Journal of Economic Literature, 1990, 28, 4, 1661-1707

[3] Campbell, R.S., Patent Trends as a Technological Forecasting Tool, In: World Patent Information, 1983, 5, 3, 137-143

[4] Fleisher, C.S., Bensoussan, B.E., Strategic and Competitive Analysis, In: Englewood Cliffs: Prentice-Hall, 2003, 347-363

[5] Choi, C., Park, Y., Monitoring the organic structure of technology based on the patent development paths, In: Technological Forecasting and Social Change, 2009, 76, 6, 754-768

[6] Lee, S., Yoon, B., Park, Y., An approach to discovering new technology opportunities: Keyword-based patent map approach, In: Technovation, 2009, 29, 6-7, 1-497

[7] Grandjean, N., Charpiot, B., Pena, C.A., Competitive intelligence and patent analysis in drug discovery: Mining the competitive knowledge bases and patents, In: J. Drug Discovery Today Technologies, 2005, 2, 3, 211-215

[8] Porter, A.L., Newman, N.C., Patent Profiling for Competitive Advantage, 2004

[9] Chunjuan, L., Quantitative analysis of patents in the global electric vehicle industry, In: Technology and Innovation Management, 2011, 32, 2, 114-116 
[10] Bengisu, M., Nekhili, R., Forecasting emerging technologies with the aid of science and technology databases, In: Technological Forecast \& Social Change, 2006, 73, 7, 835-844

[11] Meyer, P.S., Yung, J.W., Ausebel, J.H., A primer on logistic growth and substitution the mathematics of the Loglet Lab software, In: Technological Forecast \& Social Change, 1999, 6, 1, 247-271

[12] Boretos, G.P., The future of the mobile phone business, In: Technological Forecast \& Social Change, 2007, 74, 3, 331-340

[13] Yu, H.C., Chia, Y.C., Shun, C.L., Technology forecasting and patent strategy of hydrogen energy and fuel cell technologies, In: International Journal of Hydrogen Energy, 2011, 36, 12, 6957-6969

[14] Tugrul, U.D., Guillermo, R., Hilary, M., Pisek, G., Forecasting emerging technologies: use of bibliometrics and patent analysis, In: Technological Forecasting and Social Change, 2006, 73, 8, 981-1012

[15] Liu, C.Y., Wang, J.C., Forecasting the development of the biped robot walking technique in Japan through S-curve model analysis, In: Scientometrics, 2010, 82, 1, 21-36

[16] Rajeswari, A.R., Forecasting of science \& technology expenditure of India by simulation method, In: Scientometrics, 1989, 17, 3, 227-251

[17] Kim, B., Managing the transition of technology life cycle. In: Technovation, 2003, 23, 5, 371-381

[18] Cioffi, D.F., A tool for managing projects: An analytic parameterization of the S-curve, In: International Journal of Project Management, 2005, 23, 215-222

\section{Authors:}

\section{QIAN XU1,2, HUA CHENG ${ }^{1}$, YABIN YU ${ }^{1,2}$}

${ }^{1}$ School of Economics and Management, Zhejiang Sci-Tech University, Hangzhou, 310018, 5 Second Avenue, Xiasha Higher Education Zone, Hangzhou, Zhejiang, China e-mail: xuqian@cjlu.edu.cn

${ }^{2}$ School of Economics and Management, China Jiliang University, Hangzhou 310018, 258 Xueyuan Street, Xiasha Higher Education Zone, Hangzhou, Zhejiang, China

\section{Corresponding author:}

HUA CHENG

e-mail: chenghua@zstu.edu.cn 